\title{
Mesquite control increases grass density and reduces soil loss in southern Arizona
}

\author{
S. CLARK MARTIN AND HOWARD L. MORTON
}

\begin{abstract}
Authors are professor of range management (emeritus), School of Renewable Natural Resources, University of Arizona, Tucson 85721 and biological science collaborator, USDA-ARS, Aridland Watershed Management Research Unit, 2000 E. Allen Road, Tucson, Ariz. 85719. At the time the study was initiated Morton was supervisory plant physiologist, ARS, Tucson, and Martin was principal range scientist, Rocky Mountain Forest and Range Experiment Station, Tucson, which provided sites at the Santa Rita Experimental Range and funding for the study.
\end{abstract}

\section{Abstract}

In 1974 we selected 8 pairs of gully headcuts on the Santa Rita Experimental Range. Mesquite (Prosopis velutina Woot.) on the watershed of 1 headcut of each pair was killed with diesel oil. Densities of perennial grasses and shrubs, shrub cover, surface erosion, headcut advance, and gully depth were recorded at 3-year intervals, 1974-1986. Four of the watershed pairs were in pastures grazed yearlong: 4 were in Santa Rita rotations. Each grazing schedule included 2 watershed pairs that were about $200 \mathrm{~m}$ higher in elevation than the other 2 . In 1974, before mesquite was killed, perennial grass densities were low with little difference between assigned conditions. By 1977 perennial grass density was greater where mesquite was killed than on untreated watersheds and was greater at upper elevations. Lehmann lovegrass (Eragrostis Lehmanniana Nees.) made up almost all of the grass density increase at the upper elevation. Native perennial grasses, which were largely replaced by Lehmann lovegrass at the upper elevation, accounted for almost all of the gain at the lower elevation. Lower density $(P \leq 0.05)$ on low elevation rotation grazed watersheds in 1986 was the result of summer drouth in 1985 and 1986 that coincided with March-October grazing in 1986. Soil loss (mm) during each 3-year period was lower at headcut-soil surface grids where mesquite was dead. Advances in headcuts and changes in gully depth showed similar trends. On the 4 pairs of watersheds that were equipped to measure runoff, there was more total runoff per millimeter of rainfall where mesquite was alive than where mesquite was killed.

Key Words: perennial grass density, rainfall, erosion, runoff, semidesert grassland, shrub density, shrub cover

Velvet mesquite (Prosopis velutina Woot.) is an indigenous woody plant of southern Arizona. During the last century it has increased on semidesert grassland areas, as have other mesquite varieties on rangelands in New Mexico, Texas, Mexico, and Latin American countries (Leopold 1950, Parker and Martin 1952, Fisher et al. 1959, Platt 1959, Cable and Martin 1973). Herbaceous vegetation usually increases if invasion stands of mesquite are removed. For example, Parker and Martin (1952) found that basal cover and herbage production of perennial grasses more than doubled and herbage yields of annual grass increased 5-fold after mesquite was killed at 1 study site on the Santa Rita Experimental Range near Tucson, Ariz. At other sites, perennial grass production on mesquite-free plots was 2 to 7 times greater than in mesquite stands. They observed that where mesquite was killed, grass

\footnotetext{
The authors wish to acknowledge Richard Martin, Jennifer Ruyle, Pablo Lucero, Robert Wilson, Charles Fancher, and Raul Ortiz for assistance in applying the treatments, data collection, and data summary. We thank Wade Taul for preparing the figures and Dr. Gary Richardson for assistance with data analysis.

Manuscript accepted 11 Aug. 1992.
}

cover increased and soil erosion was reduced. Additional experience (Martin 1963, 1975; Reynolds and Tschirley 1963; Martin and Cable 1974) confirm these observations. Partial explanations for the effects of velvet mesquite on herbaceous cover and soil erosion are provided by Paulsen (1953) and Tiedemann and Klemmedson $(1973,1986)$. However, these reports do not include measurements of soil movement.

We began this study in 1974 to evaluate differences in erosion, runoff, and vegetation between mesquite-free and mesquiteinfested watersheds.

\section{Materials and Methods}

The study was conducted on the Santa Rita Experimental Range near Tucson, Ariz. Study areas were pairs of small gully headcuts at elevations ranging from 975 to $1,175 \mathrm{~m}$ and slopes of 2.8 to $4.2 \%$ on soils of Anthony, Comoro, and Continental series (Richardson et al. 1979, Soil Survey Staff 1975). Herbaceous vegetation was sparse and accelerated erosion was obvious at all locations when the study began. We chose gullies on a variety of range sites in order to evaluate effects of mesquite removal across a broad range of conditions.

Vegetation on study areas was typical of Southwestern grasslands that have been invaded by mesquite. The major shrubs were velvet mesquite, burroweed (Haplopappus tenuisectus [Greene] Blake ex Benson), prickly pear and cholla cactus (Opuntia spp.), little leaf baccharis (Baccharis brachyphyla Gray), and desert zinnia (Zinnia pumila Gray).

Major perennial grasses were Arizona cottontop (Digitaria californica [Benth.] Henr.), Santa Rita threeawn (Aristida glabrata [Vasey] Hitchc.), other threeawns ( $A$. hamulosa Henr. and $A$. ternipes Cav.), plains bristlegrass (Setaria macrostachya H.B.K.), Rothrock grama (Bouteloua rothrockii Vasey), Lehmann lovegrass (Eragrostis lehmanniana Nees), and bushmuhly (Muhlenbergia porteri Schribn.). Other grasses included tanglehead ( Heteropogon contortus [L.] Beauv.), Boer lovegrass (E. curvula var. conferta Ness), plains lovegrass ( $E$. intermedia Hitchc.) witchgrass (Leptoloma cognatum [Schult.] Chas.), spike dropseed (Sporobolus contractus Hitchc.), and fluffgrass (Erioneuron pulchellum Tateoka).

\section{Main Study}

The main study included 8 pairs of gully headcuts, and their $2.5-4.5$ ha watersheds. Of these, 4 pairs were about $1,170 \mathrm{~m}$ elevation where mean annual rainfall is about $350 \mathrm{~mm}$. The other 4 lie between 975 and $1,040 \mathrm{~m}$ elevation where annual rainfall is about $300 \mathrm{~mm}$. At each elevation 2 pairs of headcuts were in pastures grazed yearlong; the other 2 pairs were grazed once March-October and once November-February in a 3-year rotation with 12 months rest between grazing periods (Martin 1978). Rotation pas- 
tures were grazed $1 / 3$ of the time at triple the stocking rate for yearlong grazing. Mesquites on 1 watershed of each pair were killed with basal applications of diesel oil in 1974 with retreatment as needed to keep treated watersheds mesquite free.

Density (plants $/ \mathrm{m}^{2}$ ) at each watershed was recorded by species for perennial grasses and shrubs on 5 permanently marked belt transects $(30 \mathrm{~cm}$ by $30 \mathrm{~m})$ run perpendicular to the drainage at $15 \mathrm{~m}$ intervals above the headcut (Fig. 1). Crown intercept of shrubs was measured along the tape used to define the transect. Density and crown intercept were measured in 1974, 1977, 1980, 1983, and 1986.

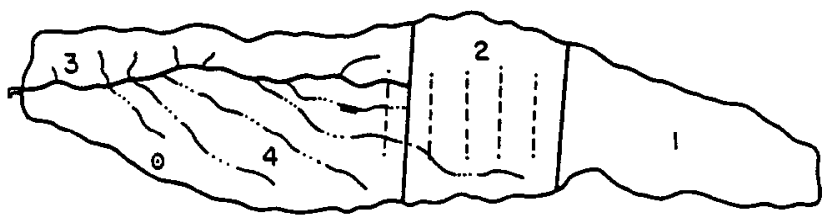

MAP LEGEND

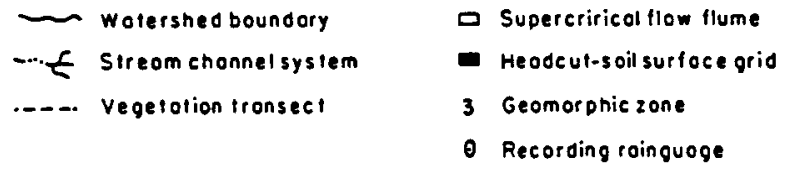

Fig. 1. Map of watershed 1c showing stream channel system, location of vegetation transects, flow nume, headcut-soil surface grid, recording rain gauge and geomorphic zones.

Erosion measurements included soil surface level, headcut advance, and gully depth. Soil surface levels at each headcut were measured at 66 points spaced $0.6 \mathrm{~m}$ apart in a 6 - by 11 -point soil-surface grid oriented lengthwise over the stream channel and centered over the initial position of the headcut (Fig. 2). Headcut position and soil surface level were remeasured in 1977, 1980, 1983, and 1986. Maximum gully depth was measured under each of the 11 transverse grid lines at each headcut in 1980, 1983, and 1986.

\section{Supplemental Study}

In a supplemental study, precipitation, runoff and sediment measurements were made on half of the watersheds ( 2 pairs at each elevation). Recording rain gauges and Replogle flumes were installed in 1975 and 1976. Flumes were equipped with automatic total load, traversing slot sediment samplers with 18-sample capacity (Renard et al. 1976). Flumes were installed $50-100 \mathrm{~m}$ downstream from the headcut soil-surface grids and received runoff in addition to what passed through the headcut. Replogle flumes were replaced with supercritical flumes (Smith et al. 1982) on watersheds $3 \mathrm{c}$ and $4 \mathrm{t}$ in May 1984 . Total precipitation, total runoff, number of runoff events, number of sediment samples and total sediment yield were computed annually for the period 1975-1988.
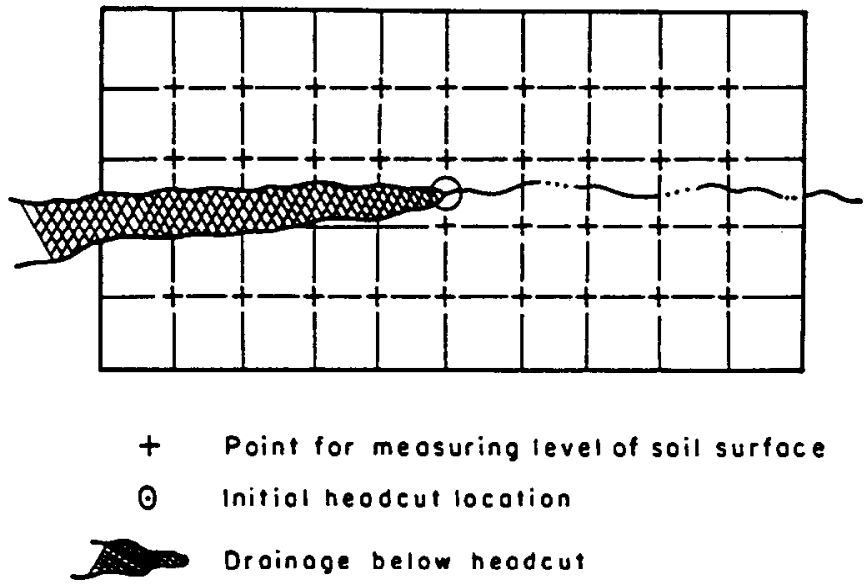

Fig. 2. Detail of headcut-soil surface grid for measuring soil loss.

\section{Statistical Analyses}

Vegetation and erosion data from the 8 pairs of watersheds were classified as a hierarchal or nested classification and analyzed by analyses of variance (Steel and Torrie 1980 p. 155). Runoff and erosion data from the subset of instrumented watersheds (4 pairs) were analyzed as paired observations as outlined by Steel and Torrie (1980 p. 102). We paired watersheds $1 \mathrm{c}$ and $2 \mathrm{t}$ (Comoro sandy loam soil series and texture, $3 \mathrm{c}$ and $4 \mathrm{t}$ (Anthony fine sandy loam soil series and texture), $5 \mathrm{c}$ and $7 \mathrm{t}$ (Continental gravelly sandy loam soil series and texture) and $8 \mathrm{c}$ and $7 \mathrm{t}$ (Continental gravelly sandy loam soil series and texture) (Table 9).

\section{Results and Discussion}

\section{Precipitation}

Summer precipitation was extremely low at both elevations in 1973; below average in 1975, 1976, 1978, 1979, 1985 and 1986; and above average in 1974, 1981, 1982, 1983, and 1984 (Table 1). Average summer precipitation during the study was higher at the upper than at the lower elevation ( $237 \mathrm{vs} 183 \mathrm{~mm}$ ). At the lower elevation mean summer rainfall was $20 \mathrm{~mm}$ higher on watersheds grazed yearlong. Mean differences in summer precipitation between yearlong- and rotation-grazed watersheds at the upper elevation were small ( $240 \mathrm{~mm}$ vs $233 \mathrm{~mm}$ ). Summer precipitation in 1977 at the low-elevation watersheds grazed yearlong was $100 \mathrm{~mm}$ greater than on those grazed in rotation.

\section{Perennial Grass Densities}

Perennial grass densities increased from 1974-77, peaked in 1983, and had declined by 1986 (Table 2). Densities were very low in 1974 and not significantly different between mesquite treatments, elevations or grazing schedules. Low densities in 1974 were

Table 1. Summer precipitation (June to September) from 1973 to 1986 at rain gauges on or near watersheds.

\begin{tabular}{|c|c|c|c|c|c|c|c|c|c|c|c|c|c|c|c|c|}
\hline \multirow[b]{2}{*}{ Elevation } & \multirow[b]{2}{*}{ Grazing } & \multicolumn{15}{|c|}{ Year } \\
\hline & & 1973 & 1974 & 1975 & 1976 & 1977 & 1978 & 1979 & 1980 & 1981 & 1982 & 1983 & 1984 & 1985 & 1986 & Mean \\
\hline & & \multicolumn{15}{|c|}{ 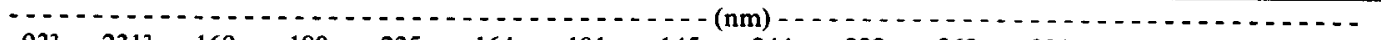 } \\
\hline Lower & Yearlong & 932 & $231^{2}$ & 169 & 180 & 235 & 164 & 101 & 145 & 244 & 222 & 268 & 301 & 172 & 166 & 192 \\
\hline Lower & Rotation & $82^{2}$ & $237^{12}$ & 130 & 130 & 1331 & 168 & 170 & $170^{1}$ & 190 & 191 & 2481 & 290 & 130 & $144^{1}$ & 172 \\
\hline Upper & Yearlong & $110^{2}$ & $315^{2}$ & $182^{2}$ & 216 & 231 & 184 & 189 & 170 & 291 & 256 & 270 & 524 & 221 & 196 & 240 \\
\hline Upper & Rotation & $110^{12}$ & $315^{2}$ & $182^{2}$ & $208^{1}$ & 204 & 170 & $194^{!}$ & 166 & 276 & $258^{1}$ & 262 & 510 & 2171 & 190 & 233 \\
\hline
\end{tabular}

Indicates years when the rotation grazed watersheds were grazed March to October

${ }^{2}$ Recording rain gauges were established on or near instrumented watersheds in 1975 and 1976. Earlier values are from nearest rain gauges in the Santa Rita rain gauge network. 
Table 2. Density (plants $/ \mathrm{m}^{2}$ ) of all perennial grasses by year and change from 1974 to 1986.

\begin{tabular}{|c|c|c|c|c|c|c|}
\hline \multirow[b]{2}{*}{ Comparison $^{1}$} & \multicolumn{5}{|c|}{ Year of Comparison } & \multirow{2}{*}{$\begin{array}{l}\text { Change } \\
1974-1986\end{array}$} \\
\hline & 1974 & 1977 & 1980 & 1983 & 1986 & \\
\hline Mesquite ${ }^{2}$ & \multicolumn{6}{|c|}{$\ldots \ldots \ldots$ (plants $\left./ m^{2}\right)-\ldots \ldots \ldots$} \\
\hline $\begin{array}{l}\text { Dead } \\
\text { Live }\end{array}$ & $\begin{array}{l}3.64 \\
3.38\end{array}$ & $\begin{array}{l}12.08^{\circ} \\
8.74\end{array}$ & $\begin{array}{c}10.66^{*} \\
6.95\end{array}$ & $\begin{array}{l}22.10^{* *} \\
13.42\end{array}$ & $\begin{array}{l}14.89^{*} \\
11.69\end{array}$ & $\begin{array}{c}11.24^{*} \\
8.31\end{array}$ \\
\hline $\begin{array}{c}\text { Elevation }{ }^{2} \\
\text { Upper } \\
\text { Lower }\end{array}$ & $\begin{array}{l}3.81 \\
3.23\end{array}$ & $\begin{array}{l}14.26^{* *} \\
6.57\end{array}$ & $\begin{array}{l}11.66^{* *} \\
5.96\end{array}$ & $\begin{array}{l}21.74^{*} \\
13.76\end{array}$ & $\begin{array}{l}14.29 \\
12.31\end{array}$ & $\begin{array}{r}10.48 \\
9.08\end{array}$ \\
\hline $\begin{array}{c}\text { Grazing }^{2} \\
\text { Yearlong } \\
\text { Rotation }\end{array}$ & $\begin{array}{l}3.20 \\
3.86\end{array}$ & $\begin{array}{r}8.70 \\
12.15\end{array}$ & $\begin{array}{l}8.06 \\
9.54\end{array}$ & $\begin{array}{l}17.50 \\
18.07\end{array}$ & $\begin{array}{l}14.92^{*} \\
11.67\end{array}$ & $\begin{array}{c}11.72^{*} \\
7.81\end{array}$ \\
\hline Mean & 3.52 & 10.43 & 8.84 & 17.78 & 13.30 & 9.78 \\
\hline
\end{tabular}

'Paired comparisons which are significantly different are indicated by symbols on the first line: $0=P \leq 0.10, *=P \leq 0.05, * *=P \leq 0.01$.

${ }^{2}$ Values for comparisons within columns may not be exactly equal due to rounding.

largely the result of exceptionally low rainfall from 1 July 1973 through June 1974 - the driest 12-month period on the Santa Rita Experimental Range since 1924. Much of the density gain from 1974 to 1977 was normal recovery from drought.

Average densities, 1977-1986, and density gains, 1974-1986, were greater on mesquite-free watersheds than on those with live mesquite ( $P \leq 0.10$ to $P \leq 0.01$ ) and were greater at the upper elevation than at the lower from 1974 to 1983. Densities, 1977-1986, were similar to average values recorded in the grazing study that involved the same pastures (Martin and Severson 1988).

Grass density was greater under yearlong grazing than under rotation grazing only in 1986 (Table 2). However, further analysis showed little difference between grazing schedules at the upper elevation; but at the lower elevation, perennial grass density was more than twice as great under yearlong grazing. We think this was the result of lower summer rainfall on the low-elevation rotationgrazed watersheds in 1985 and 1986 (Table 1) coupled with MarchOctober grazing in 1986. Similar trends were observed in an earlier study in which recovery of grass density after drought was slow if March-October grazing was imposed during summer drought or in the summer following (Martin 1973). Also, Cable and Martin (1975) reported that 2 or 3 favorable summer growing seasons are required for recovery of perennial grasses after heavy grazing during drought.

The only grasses that increased more where mesquite was killed were Arizona cottontop, Santa Rita threeawn, other threeawns and bushmuhly (Table 3). Trends suggest that plains bristlegrass declined where mesquite was killed but Rothrock grama was not affected.

The only species that increased significantly more at the upper elevation than the lower was Lehmann lovegrass. It dominated grass stands there beginning in 1977 but did not appear at all in samples at the lower elevation in 1974 and reached a density of only 0.35 plants $/ \mathrm{m}^{2}$ in 1986 . The increase in Lehmann lovegrass at the upper elevation was accompanied by decreases in Arizona cottontop, Santa Rita threeawn, other threeawns, and plains bristlegrass, all of which increased at low elevation in the absence of Lehmann lovegrass. The upper watersheds are in that part of the Experimental Range where Lehmann lovegrass has replaced much of the native perennial grass since it was introduced in 1937 (Cable 1971).

Densities of Arizona cottontop and bushmuhly increased more under yearlong than rotation grazing. Most of the increase was on the lower elevation yearlong units, which received higher rainfall than the low elevation rotation units. Responses of other native grass species to grazing schedules showed similar trends.

Mesquite control increased total grass density. Higher grass densities at the upper elevation early in the study were the result of favorable rainfall and increases in Lehmann lovegrass. As the Lehmann lovegrass stands matured, from 1983-1986, large plants crowded out seedlings of native grasses and lovegrass as well and reduced grass density at the upper elevation. Low density of Lehmann lovegrass at low elevation allowed the native grasses to be more successful there. These changes agree with Cable's (1971) observations.

Significant interactions among main effects in density changes from 1974 to 1986 support these conclusions. For example, the mesquite by elevation interaction showed the increase in perennial grass density on mesquite-free watersheds at the upper elevation to be more than one and one-half times that of any other combination. Lehmann lovegrass at the upper elevation increased one and three-fourths times as much on mesquite-free as on mesquiteinfested watersheds but increased negligibly under either grazing schedule at low elevation. Density of native perennial grasses increased only at low elevation where Lehmann lovegrass was absent or its density low. The elevation by grazing interaction showed that density of Arizona cottontop at low elevation increased over twice as much as under either grazing schedule at the upper elevation. Similarly, other grasses were many times more abundant on the low-elevation, yearlong-grazed watersheds than any other combination. Lehmann lovegrass also exhibited a grazing by mesquite interaction in which the least increase was on untreated watersheds with rotation grazing and the greatest on mesquite-free watersheds with yearlong grazing. Finally, the great-

Table 3. Perennial grass density changes (Plant/m²) by major species from 1974 to 1986.

\begin{tabular}{|c|c|c|c|c|c|c|c|c|}
\hline \multirow[b]{2}{*}{ Comparison ${ }^{1}$} & \multicolumn{8}{|c|}{ Grass species compared } \\
\hline & $\begin{array}{c}\text { Arizona } \\
\text { cottontop }\end{array}$ & $\begin{array}{c}\text { Santa Rita } \\
\text { threeawn }\end{array}$ & $\begin{array}{c}\text { Other } \\
\text { threeawns }\end{array}$ & $\begin{array}{c}\text { Plains } \\
\text { bristlegrass }\end{array}$ & $\begin{array}{c}\text { Rothrock } \\
\text { grama }\end{array}$ & $\begin{array}{l}\text { Lehmann } \\
\text { lovegrass }\end{array}$ & Bushmuhly & $\begin{array}{l}\text { Other } \\
\text { grasses }\end{array}$ \\
\hline Mesquite ${ }^{2}$ & \multicolumn{8}{|c|}{ (plants $\left./ m^{2}\right)-1, \ldots \ldots$} \\
\hline $\begin{array}{l}\text { Dead } \\
\text { Live }\end{array}$ & $\begin{array}{l}1.15^{*} \\
0.17\end{array}$ & $\begin{array}{c}0.73^{* *} \\
-0.02\end{array}$ & $\begin{array}{l}0.72^{*} \\
0.10\end{array}$ & $\begin{array}{l}-0.25^{* *} \\
0.19\end{array}$ & $\begin{array}{l}0.63 \\
0.64\end{array}$ & $\begin{array}{l}7.92 \\
4.50\end{array}$ & $\begin{array}{l}0.09^{*} \\
0.04\end{array}$ & $\begin{array}{l}0.29 \\
2.70\end{array}$ \\
\hline Elevation ${ }^{2}$ & & & & & & & & \\
\hline $\begin{array}{l}\text { Upper } \\
\text { Lower }\end{array}$ & $\begin{array}{c}-0.66^{* *} \\
1.99\end{array}$ & $\begin{array}{l}-0.28^{* *} \\
0.99\end{array}$ & $\begin{array}{c}-0.09^{* *} \\
0.9 \mathrm{I}\end{array}$ & $\begin{array}{c}-0.44^{\circ} \\
0.37\end{array}$ & $\begin{array}{l}0.00 \\
1.26\end{array}$ & $\begin{array}{l}12.06^{* *} \\
0.35\end{array}$ & $\begin{array}{r}-0.05 \\
0.18\end{array}$ & $\begin{array}{r}-0.04 \\
3.03\end{array}$ \\
\hline Grazing ${ }^{2}$ & & & & & & & & \\
\hline $\begin{array}{l}\text { Yearlong } \\
\text { Rotation }\end{array}$ & $\begin{array}{l}1.15^{*} \\
0.18\end{array}$ & $\begin{array}{l}0.60 \\
0.10\end{array}$ & $\begin{array}{l}0.50 \\
0.30\end{array}$ & $\begin{array}{r}0.22 \\
-0.28\end{array}$ & $\begin{array}{l}0.75 \\
0.51\end{array}$ & $\begin{array}{l}6.78 \\
5.62\end{array}$ & $\begin{array}{l}0.12^{*} \\
0.02\end{array}$ & $\begin{array}{l}2.97 \\
0.01\end{array}$ \\
\hline Mean & 0.66 & 0.36 & 0.41 & -0.03 & 0.63 & 6.21 & 0.06 & 1.50 \\
\hline
\end{tabular}

1Paired comparisons which are significantly different are indicated by symbols on the first line: $\bullet=P \leq 0.10, *=P \leq 0.05, * *=P \leq 0.01$.

2 Values for comparisons within columns may not be exactly equal due to rounding. 
test density gain for lovegrass was at the upper elevation (Table 3). Differences in gain between yearlong and rotation grazing were negligible but there was a trend for higher gains on mesquite-free watersheds.

Summer drought, 1975-1980, except on lower elevation watersheds that were grazed yearlong (Tables 1 and 2), was responsible for the small losses in grass density under all treatments from 1977 to 1980 .

\section{Density of Shrubs}

Total shrub density averaged about 2 plants $/ \mathrm{m}^{2}$ (Table 4). Major species were mesquite, burroweed, prickly pear and cholla

Table 4. Density (plants/ $\mathrm{m}^{2}$ ) of all shrubs by year and change from 1974 to 1986.

\begin{tabular}{|c|c|c|c|c|c|c|}
\hline \multirow[b]{2}{*}{ Comparison' } & \multicolumn{5}{|c|}{ Year of Comparison } & \multirow{2}{*}{$\begin{array}{c}\text { Change } \\
1974-1986\end{array}$} \\
\hline & 1974 & 1977 & 1980 & 1983 & 1986 & \\
\hline Mesquite $^{2}$ & \multicolumn{6}{|c|}{$-\ldots-\left(\right.$ plants $\left./ m^{2}\right)-\ldots$} \\
\hline $\begin{array}{l}\text { Dead } \\
\text { Live }\end{array}$ & $\begin{array}{l}1.77 \\
1.78\end{array}$ & $\begin{array}{l}1.76 \\
1.66\end{array}$ & $\begin{array}{l}1.56 \\
1.95\end{array}$ & $\begin{array}{l}1.42^{\circ} \\
3.01\end{array}$ & $\begin{array}{l}1.47^{\circ} \\
2.06\end{array}$ & $\begin{array}{c}-0.30^{* *} \\
0.28\end{array}$ \\
\hline $\begin{array}{c}\text { Elevation }{ }^{2} \\
\text { Upper } \\
\text { Lower }\end{array}$ & $\begin{array}{l}2.33^{* *} \\
1.23\end{array}$ & $\begin{array}{l}2.11^{* *} \\
1.30\end{array}$ & $\begin{array}{l}1.86 \\
1.65\end{array}$ & $\begin{array}{l}2.43 \\
2.00\end{array}$ & $\begin{array}{l}1.58 \\
1.95\end{array}$ & $\begin{array}{c}-0.75^{* *} \\
0.72\end{array}$ \\
\hline $\begin{array}{l}\text { Grazing }^{2} \\
\quad \text { Yearlong } \\
\text { Rotation }\end{array}$ & $\begin{array}{l}1.83 \\
1.73\end{array}$ & $\begin{array}{l}1.89 \\
1.53\end{array}$ & $\begin{array}{l}1.65 \\
1.86\end{array}$ & $\begin{array}{l}2.02 \\
2.41\end{array}$ & $\begin{array}{l}1.43^{\circ} \\
2.09\end{array}$ & $\begin{array}{l}-0.40^{* *} \\
0.36\end{array}$ \\
\hline Mean & 1.78 & 1.71 & 1.76 & 2.22 & 1.76 & -0.02 \\
\hline
\end{tabular}

'Paired comparisons which are significantly different are indicated by symbols on the first line: ${ }^{\circ}=P \leq 0.10, * *=P \leq 0.01$

2 Values for comparisons within columns may not be exactly equal due to rounding

cactus, littleleaf baccharis, and desert zinnia. Density differences associated with mesquite control were small, 1974-1980, but were higher $(P \leq 0.10)$ where mesquite was alive in 1983 and 1986 . The density change, 1974-1986, was negative where mesquite was killed but positive where mesquite was alive due largely to losses in density of burroweed and desert zinnia on mesquite-free watersheds (Table 5). Shrub densities were usually higher at the upper elevations, but were significantly greater only in 1974 and 1977. Shrub

Table 5. Shrub density changes (plants/m²) from 1974 to 1986.

\begin{tabular}{|c|c|c|c|c|}
\hline \multirow[b]{2}{*}{ Comparison' } & \multicolumn{4}{|c|}{ Species Compared } \\
\hline & Burroweed & Mesquite & Zinnia & Other \\
\hline Mesquite² & \multicolumn{4}{|c|}{ - (plants $\left./ \mathrm{m}^{2}\right)-\ldots$} \\
\hline $\begin{array}{l}\text { Dead } \\
\text { Live }\end{array}$ & $\begin{array}{r}-0.10 \\
0.20\end{array}$ & $\begin{array}{l}-0.030 \\
0.01\end{array}$ & $\begin{array}{l}-0.18 \\
-0.08\end{array}$ & $\begin{array}{l}0.01 \\
0.14\end{array}$ \\
\hline $\begin{array}{c}\text { Elevation'2 } \\
\text { Upper } \\
\text { Lower }\end{array}$ & $\begin{array}{c}-0.54^{*} \\
0.64\end{array}$ & $\begin{array}{l}0.02 \\
0.01\end{array}$ & $\begin{array}{l}-0.22^{\circ} \\
-0.04\end{array}$ & $\begin{array}{l}0.03 \\
0.12\end{array}$ \\
\hline $\begin{array}{c}\text { Grazing }^{2} \\
\text { Yearlong } \\
\text { Rotation }\end{array}$ & $\begin{array}{c}-0.34^{\circ} \\
0.44^{\circ}\end{array}$ & $\begin{array}{l}-0.01 \\
-0.01\end{array}$ & $\begin{array}{l}-0.10 \\
-0.16\end{array}$ & $\begin{array}{l}0.05 \\
0.10\end{array}$ \\
\hline Mean & 0.05 & -0.01 & -0.13 & 0.08 \\
\hline
\end{tabular}

'Paired comparisons which are significantly different are indicated by symbols on the first line: $0=P \leq 0.10, * *=P \geq 0.01$.

2Values for comparisons within columns may not be exactly equal due to rounding

densities were lower under yearlong grazing $(P \leq 0.10)$ in 1986. Significant declines in density from 1974 to 1986 were recorded for watersheds with dead mesquite, those at the upper elevation, and those with yearlong grazing. The average density of shrubs on all watersheds changed little from 1974 to 1980 , increased about $26 \%$ from 1980 to 1983 , and declined to the 1974 level in 1986.
Mesquite control reduced shrub density (1974-1986) on mesquitefree watersheds (Table 4). Density losses for burroweed and zinnia were greater on the upper watersheds and burroweed losses were greater under yearlong grazing (Table 5). Densities of perennial grasses were negatively related to densities of shrubs $(P \leq 0.01)$.

\section{Shrub Cover}

Total shrub cover, overall mean, decreased $1 / 3,1974-1977$, as mesquite crowns died on treated watersheds (Table 6). Shrub cover

Table 6. Shrub cover (\%) of all species by year and changes from 1974 to 1986.

\begin{tabular}{|c|c|c|c|c|c|c|}
\hline \multirow[b]{2}{*}{ Comparison $^{1}$} & \multicolumn{5}{|c|}{ Year of Comparison } & \multirow{2}{*}{$\begin{array}{c}\text { Change } \\
1974-1986\end{array}$} \\
\hline & 1974 & 1977 & 1980 & 1983 & 1986 & \\
\hline Mesquite2 & \multicolumn{6}{|c|}{$-1 \%$ (\%) } \\
\hline $\begin{array}{l}\text { Dead } \\
\text { Live }\end{array}$ & $\begin{array}{l}26.6 \\
21.3\end{array}$ & $\begin{array}{l}9.7^{* *} \\
20.7^{*}\end{array}$ & $\begin{array}{l}16.6 \\
28.3\end{array}$ & $\begin{array}{l}15.1^{*} \\
31.0\end{array}$ & $\begin{array}{l}18.1^{* *} \\
33.0\end{array}$ & $\begin{array}{r}-8.5 \\
11.7\end{array}$ \\
\hline $\begin{array}{c}\text { Elevation }{ }^{2} \\
\text { Upper } \\
\text { Lower }\end{array}$ & $\begin{array}{l}28.8^{*} \\
19.1\end{array}$ & $\begin{array}{l}18.5^{*} \\
11.9\end{array}$ & $\begin{array}{l}23.8 \\
21.1\end{array}$ & $\begin{array}{l}30.0^{*} \\
16.1\end{array}$ & $\begin{array}{l}29.1 \\
21.9\end{array}$ & $\begin{array}{l}0.3 \\
2.8\end{array}$ \\
\hline $\begin{array}{l}\text { Grazing }{ }^{2} \\
\text { Yearlong } \\
\text { Rotation }\end{array}$ & $\begin{array}{l}25.9 \\
22.0\end{array}$ & $\begin{array}{l}14.9 \\
15.6\end{array}$ & $\begin{array}{l}20.2 \\
24.6\end{array}$ & $\begin{array}{l}21.3 \\
24.9\end{array}$ & $\begin{array}{l}24.3 \\
26.7\end{array}$ & $\begin{array}{r}-1.6 \\
4.7\end{array}$ \\
\hline Mean & 24.0 & 15.2 & 22.4 & 23.1 & 25.5 & 1.5 \\
\hline
\end{tabular}

I Paired comparisons which are significantly different are indicated by symbols on the first line: $*=P \leq 0.05, * *=P \leq 0.01$

2Values for comparisons within columns may not be exactly equal due to rounding.

on treated watersheds, where mesquite initially made up $56 \%$ of the total, declined almost $2 / 3,1974-1977$, then regained about half the loss by 1986 . Burroweed made up most of the shrub cover increase, 1977-1986, on both treated and untreated watersheds. Shrub cover was higher at the upper elevation but was not significantly different between grazing schedules. Losses in cover, 1974-1986, with mesquite control were significant for mesquite and zinnia (Table 7). General trends were positive for burroweed, negative for baccharis.

Table 7. Shrub cover (\%) changes between 1974 and 1986 by species.

\begin{tabular}{|c|c|c|c|c|c|c|}
\hline \multirow[b]{2}{*}{ Comparison' } & \multicolumn{6}{|c|}{ Cover change } \\
\hline & $\begin{array}{l}\text { Burro- } \\
\text { weed }\end{array}$ & $\begin{array}{l}\text { Mes- } \\
\text { quite }\end{array}$ & $\begin{array}{l}\text { Bac- } \\
\text { charis }\end{array}$ & Cactus & Zinnia & Other \\
\hline & \multicolumn{6}{|c|}{. $\%$ Cover change) } \\
\hline $\begin{array}{l}\text { Mesquite } \\
\text { Dead } \\
\text { Live }\end{array}$ & $\begin{array}{l}7.26 \\
6.93\end{array}$ & $\begin{array}{c}-14.79 * * \\
2.69\end{array}$ & $\begin{array}{r}-0.60 \\
0.14\end{array}$ & $\begin{array}{l}0.16 \\
0.19\end{array}$ & $\begin{array}{l}-0.71^{*} \\
-0.18\end{array}$ & $\begin{array}{r}-0.02 \\
1.89\end{array}$ \\
\hline $\begin{array}{l}\text { Elevation }{ }^{2} \\
\text { Upper } \\
\text { I ower }\end{array}$ & $\begin{array}{l}8.06 \\
6.13\end{array}$ & $\begin{array}{l}-7.44 \\
-4.58\end{array}$ & $\begin{array}{l}-0.21 \\
-0.25\end{array}$ & $\begin{array}{r}0.65 \\
-0.29\end{array}$ & $\begin{array}{l}-0.64^{\circ} \\
-0.25\end{array}$ & $\begin{array}{c}-0.12^{\circ} \\
2.03\end{array}$ \\
\hline $\begin{array}{l}\text { Grazing }{ }^{2} \\
\text { Yearlong } \\
\text { Rotation }\end{array}$ & $\begin{array}{l}7.33 \\
6.86\end{array}$ & $\begin{array}{l}-6.84 \\
-5.18\end{array}$ & $\begin{array}{l}-0.32 \\
-0.14\end{array}$ & $\begin{array}{r}0.52 \\
-0.15\end{array}$ & $\begin{array}{l}-0.48 \\
-0.41\end{array}$ & $\begin{array}{l}0.20 \\
1.70\end{array}$ \\
\hline Mean & 7.10 & -6.01 & -0.23 & 0.18 & -0.44 & 0.95 \\
\hline
\end{tabular}

1 Paired comparisons which are significantly different are indicated by symbols on the first line: $0=P \leq 0.10, *=P \leq 0.05, * *=P \leq 0.01$.

${ }^{2}$ Values for comparison within columns may not be exactly equal due to rounding.

Soil Sheet Erosion, Headcut Advance and Changes in Gully Depth

Soil loss at headcut soil-surface grids was always greater on watersheds with live mesquite than where mesquite was killed (Table 8). Soil loss was consistently greater at the lower elevation but the difference was significant ( $P \leq 0$.10) only from $1977-1980$. Differences in soil loss between yearlong and rotation grazing were erratic due to differences among watersheds in soil, slope, and 
Table 8. Soil loss (mm) during four 3-year intervals from 1974 to 1986, headcut advance (m) from 1974 to 1986, and changes in gully depth (cm) from 1980 to 1986.

\begin{tabular}{|c|c|c|c|c|c|c|c|}
\hline \multirow[b]{2}{*}{ Comparison ${ }^{1}$} & \multicolumn{4}{|c|}{ Soil loss } & \multirow{2}{*}{$\begin{array}{l}\text { Headcut } \\
\text { advance }\end{array}$} & \multicolumn{2}{|c|}{ Change in gully depth } \\
\hline & $1974-1977$ & $1977-1988$ & $1980-1983$ & $1983-1986$ & & $1980-1983$ & $1983-1986$ \\
\hline Mesquite $^{2}$ & \multicolumn{4}{|c|}{ 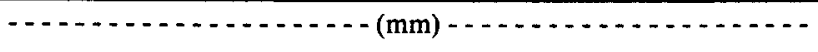 } & (m) & \multicolumn{2}{|c|}{$-\ldots-\ldots(\mathrm{cm}) \cdots \ldots$} \\
\hline $\begin{array}{l}\text { Dead } \\
\text { Live }\end{array}$ & $24^{1 *}$ & $\begin{array}{l}9^{* * *} \\
34\end{array}$ & $\begin{array}{l}18^{*} \\
58\end{array}$ & $\begin{array}{l}15^{\circ} \\
75^{\circ}\end{array}$ & $\begin{array}{l}1.8 \\
4.9\end{array}$ & $\begin{array}{r}-0.7 \\
6.7\end{array}$ & $\begin{array}{l}-1.6 \\
-0.7\end{array}$ \\
\hline Elevation ${ }^{2}$ & & & & & & & \\
\hline $\begin{array}{l}\text { Upper } \\
\text { Lower }\end{array}$ & $\begin{array}{l}10 \\
15\end{array}$ & $\begin{array}{l}15^{\circ} \\
28\end{array}$ & $\begin{array}{l}27 \\
48\end{array}$ & $\begin{array}{l}40 \\
50\end{array}$ & $\begin{array}{l}3.2 \\
3.5\end{array}$ & $\begin{array}{l}2.7 \\
3.5\end{array}$ & $\begin{array}{r}1.8 \\
-4.0\end{array}$ \\
\hline $\begin{array}{l}\text { Grazing }{ }^{2} \\
\text { Yearlong } \\
\text { Rotation }\end{array}$ & $\begin{array}{r}20 \\
5\end{array}$ & $\begin{array}{l}17 \\
27\end{array}$ & $\begin{array}{l}44 \\
32\end{array}$ & $\begin{array}{l}50 \\
40\end{array}$ & $\begin{array}{l}4.2 \\
2.6\end{array}$ & $\begin{array}{l}2.9 \\
3.3\end{array}$ & $\begin{array}{l}-0.9 \\
-1.3\end{array}$ \\
\hline Mean & 13 & 22 & 38 & 45 & 3.4 & 3.1 & -1.1 \\
\hline
\end{tabular}

'Paired comparisons which are significantly different are indicated by symbols on the first line: $0=P \leq 0.10, *=P \leq 0.05, * *=P \leq 0.01$.

2Values for comparison within columns may not be exactly equal due to rounding.

precipitation. Mean soil loss was higher in 19801986 than in 1974-1980, possibly due to the higher rainfall in 1983 and 1984 (Table 1).

Headcut advances and increases in gully depth were consistently greater for watersheds with live mesquite than where mesquite was killed but neither measure showed consistent trends associated with differences in elevation or grazing schedule (Table 8). Average increases in gully depth, 1980-1983, were almost 3 times as great as from 1983 to 1986 as silt deposits reduced the depths of some gullies.

\section{Supplemental Studies}

\section{Runoff and Sediment Yield}

Kunoff and sediment yield were measured only on the 4 pairs of instrumented watersheds. Descriptions of the watersheds including stream channel lengths, geomorphic zones, and overall slope are presented in Table 9 and Figure 1. Mean runoff was higher $(P \leq 0.05)$ where mesquite was alive $(7 \%)$ than where it was dead (5.5\%) (Table 10). Reductions in runoff from watersheds where mesquite was killed are consistent with erosion data from the main study (Table 8) and with Gould's report (1982) of reduced wind erosion after controlling honey mesquite $(P$. glandulosa [Torr.] Cockll.) in New Mexico.

A tracer study on watersheds $1 c$ and $2 t$ in 1976 (Lane et al. 1977) indicated that no runoff came from the upper part (Zone 1 of either watershed (Fig. 1). The mid sections (Zone 2) of watersheds lc and $2 t$ contributed 13 and $36 \%$ of the total runoff. Zones and 3 and 4 , which were closest to the flume, produced most of the runoff $(87$ and $64 \%$, respectively) for watersheds $1 \mathrm{c}$ and $2 \mathrm{t}$ in 1976 . These data help explain apparent differences between erosion indicators recorded at the flumes and those from the headcut soil-surface grids. For example, only 1 of the 5 plant density transects lay in zone 3 or 4 and that one was near the upper edge of the high runoff area. The other 4 transects were located in zone 2 , which contributed only modest amounts of silt. Also, the transects sampled about 0.5 ha of watershed immediately above the headcut soilsurface grids, less than $20 \%$ of the drainage area for the flumes. Consequently, vegetation conditions on the transects affected erosion rates on the headcut grids much more strongly than they

Table 9. Watershed number, grazing schedule, elevation, stream channel length, watershed slope, soil series, texture, and classification for instrumented watersheds.

\begin{tabular}{|c|c|c|c|c|c|c|}
\hline $\begin{array}{l}\text { Watershed } \\
\text { number }\end{array}$ & $\begin{array}{l}\text { Grazing } \\
\text { schedule }\end{array}$ & Elevation & $\begin{array}{l}\text { Stream } \\
\text { length }\end{array}$ & $\begin{array}{l}\text { Watershed } \\
\text { slope }\end{array}$ & Soil series \& texture ${ }^{3}$ & Classification \\
\hline lc & Yearlong & $\begin{array}{l}(\mathrm{m}) \\
1040\end{array}$ & $\begin{array}{c}(\mathrm{m}) \\
329\end{array}$ & $\begin{array}{l}(\%) \\
4.1\end{array}$ & Comoro sandy loam & $\begin{array}{l}\text { coarse-loamy, mixed thermic } \\
\text { Typic Torrifluvents }\end{array}$ \\
\hline $2 t$ & Yearlong & 1040 & 256 & 4.0 & Comoro sandy loam & $\begin{array}{l}\text { coarse-loamy, mixed thermic } \\
\text { Typic Torrifluvents }\end{array}$ \\
\hline $3 c$ & Rotation & 975 & 298 & 2.8 & Anthony fine sandy loam & $\begin{array}{l}\text { coarse-loamy, mixed (calcareous) } \\
\text { thermic Typic Torrifluvents }\end{array}$ \\
\hline $4 t$ & Rotation & 1010 & 306 & 3.7 & Anthony fine sandy loam & $\begin{array}{l}\text { coarse-loamy, mixed (calcareous) } \\
\text { thermic Typic Torrifluvents }\end{array}$ \\
\hline $5 c$ & Rotation & 1175 & 1203 & 3.9 & $\begin{array}{l}\text { Continental gravelly } \\
\text { sandy loam }\end{array}$ & $\begin{array}{l}\text { fine, mixed, thermic } \\
\text { Typic Haplargids }\end{array}$ \\
\hline $6 \mathrm{t}$ & Rotation & 1160 & 470 & 3.5 & Comoro sandy loam & $\begin{array}{l}\text { coase-loamy, mixed thermic } \\
\text { Typic Torrifluvents }\end{array}$ \\
\hline $7 t$ & Yearlong & 1175 & 230 & 4.0 & $\begin{array}{l}\text { Continental gravelly } \\
\text { sandy loam }\end{array}$ & $\begin{array}{l}\text { fine, mixed, thermic } \\
\text { Typic Haplargids }\end{array}$ \\
\hline $8 c$ & Yearlong & 1175 & 404 & 4.2 & $\begin{array}{l}\text { Continental gravelly } \\
\text { sandy loam }\end{array}$ & $\begin{array}{l}\text { fine, mixed, thermic } \\
\text { Typic Haplargids }\end{array}$ \\
\hline
\end{tabular}

1The letters after the watershed numbers indicate the mesquite treatment: $c=$ control or live mesquite and $t=$ treated or dead mesquite.

$t=$ treated or dead mesquite.

${ }^{2}$ Rotation watersheds were grazed under the Santa Rita Grazing schedule from March through October 1 year in 3 and from November through February 1 year in 3 with 12 months between grazing periods (Martin 1978). 
Table 10. Precipitation and runoff $(\mathrm{mm})$ on instrumented watersheds from 1976 through 1988.

\begin{tabular}{|c|c|c|c|c|c|c|c|c|c|c|c|c|c|c|c|}
\hline \multicolumn{2}{|c|}{ Watershed } & \multicolumn{14}{|c|}{ Precipitation/Runoff } \\
\hline Number ${ }^{\prime}$ & Slope & 1976 & 1977 & 1978 & 1979 & 1980 & 1981 & 1982 & 1983 & 1984 & 1985 & 1986 & 1987 & 1988 & Mean \\
\hline & (\%) & & 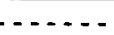 & & & & & 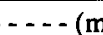 & 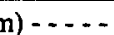 & & & & 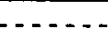 & 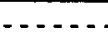 & \\
\hline lc & 4.1 & $306 / 11$ & $463 / 40$ & $511 / 30$ & $253 / 5$ & $251 / 7$ & $358 / 40$ & $325 / 16$ & $564 / 54$ & $459 / 11$ & $318 / 2$ & $296 / 10$ & $324 / 11$ & $344 / 25$ & $367 / 20$ \\
\hline $2 \mathrm{t}$ & 4.0 & $296 / 9$ & $430 / 47$ & $551 / 33$ & $262 / 2$ & $266 / 2$ & $389 / 30$ & $357 / 11$ & $641 / 18$ & $508 / 4$ & $361 / 1^{2}$ & $358 / 5$ & $355 / 8$ & $384 / 19$ & $397 / 14$ \\
\hline $3 c$ & 2.8 & $202 / 6$ & $345 / 41$ & $589 / 88$ & $341 / 30$ & $269 / 21$ & $367 / 35$ & $324 / 61$ & $620 / 150$ & $541 / 39$ & $352 / 14$ & $291 / 14$ & $401 / 20$ & $326 / 37$ & $382 / 43$ \\
\hline $4 t$ & 3.7 & $241 / 18$ & $345 / 36$ & $515 / 85$ & $320 / 38$ & $242 / 26$ & $329 / 40$ & $321 / 49$ & $586 / 80$ & $470 / 37$ & $303 / 20$ & $280 / 23$ & $366 / 27$ & $338 / 31$ & $358 / 39$ \\
\hline $5 c$ & 3.9 & $315 / 14$ & $422 / 21$ & $559 / 21$ & $361 / 16$ & $273 / 4$ & $432 / 42$ & $406 / 17$ & $586 / 23$ & $711 / 67$ & $425 / 2$ & $333 / 3$ & $537 / 8$ & $513 / 22$ & $452 / 20$ \\
\hline $6 \mathrm{t}$ & 3.5 & $304 / 3$ & $424 / 2$ & $580 / 4$ & $371 / 4$ & $297 / 1^{2}$ & $465 / 4$ & $450 / 1$ & $593 / 1$ & $760 / 8$ & $431 / 1^{2}$ & $340 / 1^{2}$ & $507 / 1^{2}$ & $513 / 1$ & $465 / 2$ \\
\hline $7 \mathrm{t}$ & 4.0 & $310 / 15$ & $457 / 24$ & $638 / 44$ & $355 / 24$ & $292 / 6$ & $433 / 57$ & $406 / 19$ & $593 / 35$ & $698 / 125$ & $418 / 8$ & $321 / 4$ & $512 / 10$ & $518 / 22$ & $458 / 30$ \\
\hline $8 c$ & 4.2 & $310 / 16$ & $457 / 33$ & $638 / 50$ & $388 / 29$ & $298 / 12$ & $484 / 47$ & $456 / 28$ & $652 / 45$ & $813 / 115$ & $506 / 10$ & $384 / 8$ & $581 / 26$ & $588 / 44$ & $505 / 36$ \\
\hline
\end{tabular}

${ }^{1}$ Watersheds numbers followed by $\mathrm{c}$ are those with live mesquite and those followed by $\mathrm{t}$ are those with dead mesquite.

${ }^{2} \mathrm{~T}=$ Less than $0.5 \mathrm{~mm}$ of runoff.

affected measurements at the flumes.

Variances were high for runoff and erosion due to differences among watersheds in soil characteristics, vegetation cover, slope, stream length, sizes of geomorphic zones, and rainfall amounts and intensities. For example, total sediment yields, 1975-1988, ranged from $103,551 \mathrm{~kg} / \mathrm{ha}$ on watershed $4 \mathrm{t}$ at the lower elevation to 307 $\mathrm{kg} / \mathrm{ha}$ on upper elevation watershed 6t. Both were rotation grazed and mesquite free. Sediment yield was 2.5 times greater at the lower than at the upper watersheds; and over 3 times as much sediment came from watersheds grazed in rotation as from those grazed yearlong, but these differences were not significant. Even so, runoff as a portion of the total amount of precipitation that fell on the watersheds was greater for watersheds with live mesquite than where mesquite was killed $(P \leqq 0.05)$. Comparisons between mesquite-free and mesquite-infested watersheds with respect to numbers of runoff events, numbers of sediment samples, and sediment yield showed similar trends.

\section{Conclusions}

Density of perennial grasses increased on watersheds where mesquite was killed. Higher grass density on mesquite-free watersheds reduced runoff and soil movement below levels recorded where mesquite was alive.

\section{Literature Cited}

Cable, D.R. 1971. Lehmann lovegrass on the Santa Rita Experimental Range. 1937-1968. J. Range Manage. 24:17-21.

Cable, D.R., and S.C. Martin. 1973. Invasion of semidesert grassland by velvet mesquite and associated vegetation changes. Arizona Acad. Sci. 8:127-134.

Fisher, C.E., C.H. Meadors, R. Behrens, E.D. Robinson, P.T. Marion, and H.L. Morton. 1959. Control of mesquite on grazing lands. Texas Agr. Exp. Sta. Bull. 935.

Gould, W.L. 1982. Wind erosion curtailed by controlling mesquite. J. Range Manage. 35:563-566.

Green, C.R., and S.C. Martin. 1967. An evaluation of precipitation, vegetation, and related factors on the Santa Rita Experimental Range. Institute of Atmospheric Physics. Univ. Arizona. Tech. Rep. on Meteorolugy and Climatology of Arid Regions. 17.
Lane, L.J., H.L. Morton, D.E. Wallace, R.E. Wilson, and R.D. Martin. 1977. Nonpoint-source pollutants to determine runoff source areas. Hydrol. and Water Resources in Arizona and the Southwest. 7:89-102. Leopold, A.S. 1950. Vegetational zones of Mexico. Ecol. 31:507-518.

Martin, S.C. 1963. Grow more grass by controlling mesquite. Coll. of Agr. Univ. Arizona Progressive Agr. in Arizona. 15:15-16.

Martin, S.C. 1975. Ecology and management of southwestern semidesert grass-shrub ranges: the status of our knowledge. USDA, forest Serv. Res. Paper RM-156.

Martin, S.C. 1978. The Santa Rita grazing system. p. 573-575. In: D.N Hyder (ed.), Proc. Ist Int. Rangeland Congress, Soc. Range Manage. Denver, Colo.

Martin, S.C., and D.R. Cable. 1974. Managing semidesert grass-shrub ranges vegetation responses to precipitation, grazing, soil texture, and mesquite control. USDA, Forest Serv., Tech. Bull. 1480.

Martin, S.C., and K.E. Severson. 1988. Vegetation response to the Santa Rita grazing system. J. Range Manage. 41:291-295.

Parker, K.W., and S.C. Martin. 1952. The mesquite problem on southern Arizona Ranges. USDA Cir. 908.

Paulsen, H.A., Jr. 1953. A comparison of surface soil properties under mesquite and perennial grass. Ecol. 34:727-732.

Platt, K.B. 1959. Plant control-Some possibilities and limitations I. The challenge to management. J. Range Manage. 12:64-68.

Renard, K.G., J.R. Simanton, and L.D. Donica. 1976. A time-related automatic total-load sediment sampler, p. 7-17-7-29. In: Proc. 3rd Federal Inter-agency Sedimentation Conf., Sedimentation Comm., Water Resources Council, Washington, D.C.

Reynolds, H.G., and F.H. Tschirley, 1963. Mesquite control on southwestern rangeland. USDA Leaflet 421 .

Richardson, M.L., S.D. Clemmons, and J.C. Walker. 1979. Soil survey of Santa Cruz and parts of Pima Counties, Arizona. USDA, Soil Conserv. Serv., and Forest Serv.; and Arizona Agr. Fxp. Sta.

Smith, R.E., D.L. Chery, Jr., K.G. Renard, and W.R. Gwinn. 1982. Supercritical flow flumes for measuring sediment laden flow. USDAARS Tech. Bull. 1655.

Soil Survey Staff. 1975. Soil taxonomy: a basic system of soil classification for making and interpreting soil surveys. USDA-SCS Agr. Handb. 436.

Steel, R.G.D., and J.H. Torrie. 1980. Principles and procedures of statistics-A biometrical approach. 2nd Ed. McGraw-Hill Book Co. N.Y.

Tiedemann, A.R., and J.O. Klemmedson. 1973. Effect of mesquite on physical and chemical properties of the soil. J. Range Manage. 26:27-29.

Tiedemann, A.R., and J.O. Klemmedson. 1986. Long-term effects of mesquite removal on soil characteristics: I. Soil nutrients and bulk density. Soil Sci. Soc. Amer. J. 50:476-480. 